Article

\title{
Effects of between and within Herd Moves on Elephant Endotheliotropic Herpesvirus (EEHV) Recrudescence and Shedding in Captive Asian Elephants (Elephas maximus)
}

\author{
Sanna Eriksson Titus ${ }^{1,2, * \mathbb{D}}$, Stuart Patterson ${ }^{2} \mathbb{D}$, Joanna Prince-Wright ${ }^{3}$, Akbar Dastjerdi ${ }^{3}$ \\ and Fieke Marije Molenaar ${ }^{4}(\mathbb{D}$
}

Citation: Titus, S.E.; Patterson, S.; Prince-Wright, J.; Dastjerdi, A.;

Molenaar, F.M. Effects of between and within Herd Moves on Elephant Endotheliotropic Herpesvirus (EEHV) Recrudescence and Shedding in Captive Asian Elephants (Elephas maximus). Viruses 2022, 14, 229. https://doi.org/10.3390/ v14020229

Academic Editor:

Shafiqul Chowdhury

Received: 15 December 2021

Accepted: 18 January 2022

Published: 24 January 2022

Publisher's Note: MDPI stays neutral with regard to jurisdictional claims in published maps and institutional affiliations.

Copyright: (C) 2022 by the authors. Licensee MDPI, Basel, Switzerland. This article is an open access article distributed under the terms and conditions of the Creative Commons Attribution (CC BY) license (https:// creativecommons.org/licenses/by/ $4.0 /$ )
1 Institute of Zoology, Zoological Society of London, Regents Park, London NW1 4RY, UK

2 Royal Veterinary College, Royal College Street, London NW1 0TU, UK; spatterson@rvc.ac.uk

3 Animal and Plant Health Agency (APHA)-Weybridge, Woodham Lane, New Haw, Addlestone, Surrey KT15 3NB, UK; Joanna.Prince-Wright@apha.gov.uk (J.P.-W.); akbar.dastjerdi@apha.gov.uk (A.D.)

4 ZSL Whipsnade Zoo, Part of the Zoological Society of London, Regents Park, London NW1 4RY, UK; fieke.molenaar@zsl.org

* Correspondence: stitus20@rvc.ac.uk

\begin{abstract}
Haemorrhagic disease associated with elephant endotheliotropic herpesvirus (Elephantid herpesvirus, EEHV) infections is the leading cause of death for Asian elephant (Elephas maximus) calves. This study assessed the effect of captive herd management on EEHV shedding, as evidence of latent infection reactivation, focusing on: (1) the influence of social change on the odds of recrudescence; (2) the respective effects of between and within herd moves; and (3) characteristics of recrudescent viral shedding. Trunk and conjunctival swabs $(n=165)$ were obtained from six elephants at an EAZA-accredited zoo, collected during a period of social stability, and at times of social change. Longitudinal sampling took place at times of moving two bulls out of the collection and one new bull into an adjacent enclosure to the cow herd (between herd moves), and during a period of mixing this new bull with the cow herd to facilitate mating (within herd moves). Quantitative PCR was employed to detect EEHV $1 \mathrm{a} / \mathrm{b}, 4 \mathrm{a} / \mathrm{b}$, and EF-1- $\alpha$ (housekeeping gene). Generalised estimating equations determined EEHV recrudescence odds ratios (OR) and relative viral DNA load. Sixteen EEHV $1 \mathrm{a} / \mathrm{b}$ shedding events occurred, but no EEHV $4 \mathrm{a} / \mathrm{b}$ was detected. All management-derived social changes promoted recrudescence (social change $\mathrm{OR}=3.27,95 \% \mathrm{CI}=0.412-26, p=0.262$; and between herd moves $\mathrm{OR}=1.6,95 \% \mathrm{CI}=0.178-14.4, p=0.675)$, though within herd movements posed the most significant increase of EEHV reactivation odds $(\mathrm{OR}=6.86,95 \% \mathrm{CI}=0.823-57.1, p=0.075)$ and demonstrated the strongest relative influence (post hoc Tukey test $p=0.0425$ ). Shedding onset and magnitude ranged from six to 54 days and from 3.59 to $11.09 \Delta \mathrm{Cts}$. Differing challenges are associated with between and within herd movements, which can promote recrudescence and should be considered an exposure risk to naïve elephants.
\end{abstract}

Keywords: Elephas maximus; elephant endotheliotropic herpesvirus; recrudescence; management; social change; qPCR

\section{Introduction}

The haemorrhagic disease (HD) process associated with clinical elephant endotheliotropic herpesvirus (elephantid herpesvirus, EEHV) infections is the leading cause of death in captive Asian elephant (Elephas maximus) calves in Europe and North America [1,2]. This virus is responsible for $20 \%$ of all Asian elephant deaths in Western zoos over the last 30 years and 65\% of all fatalities in North America [2,3]. Between 1985 and 2017, EEHV-HD caused $57 \%$ of calf mortalities in Europe [1]. For the past forty years, Asian elephants have been categorised as 'endangered' and decreasing on the International Union for the Conservation of Nature's Red List [4]. Captive collections are especially vulnerable to 
HD mortalities [1,5], which are essential for species conservation by serving as a reserve for genetic diversity, research, and future reintroduction initiatives. Both in- and ex-situ breeding programmes are presently unsustainable due to the effects of EEHV-HD, and if current trends continue, captive Asian elephants in North America will be demographically extinct before 2050 [6-8]. Intense monitoring and prevention remain the most efficient approach to controlling infections and the risk of HD-associated death, as EEHV lacks an effective antiviral treatment and vaccination strategy. Key considerations to understand EEHV epidemiology include prevalence, exposure routes, drivers of recrudescence, and the role of latent carriers. Within the last decade, EEHV prevalence and exposure routes have been defined, but researchers have called for greater understanding of recrudescent cases and actions promoting viral shedding $[5,6,9]$.

Taxonomised into an exclusive Proboscivirus genus within the Herpesviridae family, there are presently seven known EEHV genotypes (EEHV-1 to -7) [1,5]. Asian elephants, the most likely species to develop clinical HD, are susceptible to $1 \mathrm{a} / \mathrm{b}, 4 \mathrm{a} / \mathrm{b}$ and $5 \mathrm{a} / \mathrm{b}[5,10]$. Polymerase chain reactions (PCR) and DNA sequencing are widely used to differentiate genotypes and have proven that each captive collection harbours unique EEHV strains [11-13]. Cross protection against different variants post-exposure has not been proven, co-infection is possible, and pathogenicity varies [14-16]. For primary infections, incubation can last up to two weeks, followed by viraemia and onset of viral shedding about a week later [17]. Although transmission routes have not yet been proven, mucosal secretion and saliva are the most probable avenues of viral exchange [17-19]. Between herd moves, which involves the transport of elephants between facilities, may allow restricted trunk contact, and can therefore expose the resident herd to EEHV through saliva and trunk secretions. Within herd moves is synonymous with unrestricted direct mingling, thus exposing other elephants to potentially infected bodily fluids when mating. EEHV $1 \mathrm{a}$ is responsible for $80 \%$ of HD deaths in European zoos (20 cases total between 1985 to 2017 ) and $1 b$ appears the second-most pathogenic [1,20]. Both EEHV $4 \mathrm{a} / \mathrm{b}$ and 5a/b infections have also each led to one HD fatality in Europe $[15,21,22]$. Salivary glands and the gastrointestinal system serve as tissue tropism for EEHV 1a and EEHV 4 infections [18]. Calves with EEHV-HD demonstrate increased infiltration of Iba-1-positive macrophages in the inflamed tissues of internal organs [23]. The nuclei of sublingual salivary glands are typically more enlarged and greater lymphohistiocytic inflammatory cell infiltration occurs in EEHV 1a cases when compared to EEHV 4 [18]. Inversely, calves with EEHV 4 sometimes exhibit higher instances of gastric mucosal haemorrhage than EEHV 1a infections [18]. Cellular apoptosis is elevated within the tissues of EEHV-HD patients, particularly within peripheral blood mononuclear cells [23]. Elephants experiencing primary exposure to high viral loads are susceptible to HD [5,24,25]. High EEHV viral loads are correlated to severe clinical signs, which, for example, may develop from lethargy and petechiae to oedema and cyanosis [26,27]. HD is particularly challenging to manage due to its rapid progression from clinical signs to per acute death, which can occur within 36 hours [28-30]. The mortality rate has recently improved due to rapid veterinary intervention and improved treatment before significant vascular damage occurs [31,32]. Nevertheless, $70 \%$ of primary global EEHV infections have been fatal within one to seven days $[5,28,33]$.

Parallel to other herpesviruses, elephants who survive primary EEHV infections remain life-long carriers $[5,11,30]$. Recrudescence of latent EEHV infections is attributed to immunosuppression, typically involving stress or chemical agents [25,34]. Virus circulation among asymptomatic individuals has been documented $[6,30,35]$, and a study by Hoornweg et al. (2021) suggests EEHV omnipresence, as $97.5 \%(n=41)$ and $100 \%(n=69)$ of screened Asian elephants from European zoos and Laotian semi-captivity were seropositive, respectively [3]. Hence, some researchers advise all adult captive Asian elephants should be considered as EEHV carriers [1,36,37]. The danger posed by latent carriers to naïve individuals, however, remains largely unexplored. It is not known at which viral threshold EEHV is infectious, how fast viral shedding commences following a trigger event, or the duration of shedding. 
Some facilities, interestingly, have not experienced fatal HD, such as Kölner Zoo (Germany) and Zoo Emmen (the Netherlands) [38]. A novel meta-analysis of European Association of Zoos and Aquariums (EAZA) member institutions found that the only significant risk factor for infected calves to succumb to HD death was a history of fatal EEHV-HD at the facility [1]. It has been hypothesised that these zoos circulate less pathogenic or virulent strains [2,5], or retain minimal prevalence by means of genetic factors [1]. This article will explore whether it is also possible that particular management factors can influence viral loads.

Literature exploring the relationship between management interventions and EEHV reactivation is limited. Hengtrakul et al. (2020) found that construction, new keepers, and changing holding areas had no effect on EEHV shedding [39]. Otherwise, EEHV recrudescent cases are sporadically published, and the majority describe inter-herd circulation $[33,40,41]$. There are two reports documenting instances of increased EEHV shedding following social change [42,43]. The first demonstrates the effect of a between herd move, where two calves actively shedding EEHV presented inverse responses following the arrival of a new bull: the male experienced a peak of EEHV $5 \mathrm{a} / \mathrm{b}$ viral loads while the female stabilised EEHV 1a/b shedding loads [42]. Bennett et al. (2015) researched whether pregnancy increased EEHV shedding, but instead documented six months of continuous shedding from the herd following a change in matriarchal hierarchy [43]. Though these examples illustrate an association between social change and viral shedding, the isolated strength and direction of this relationship have yet to be established.

This study, therefore, aims to assess the effect of specific changes in Asian elephant herd management on EEHV $1 \mathrm{a} / \mathrm{b}$ and $4 \mathrm{a} / \mathrm{b}$ shedding, as evidence of latent infection recrudescence. The objectives are to determine whether social change influences the odds of EEHV recrudescence or shedding load for individual elephants, analyse the isolated effect of between and within herd moves, and evaluate the characteristics of recrudescent viral shedding. Conclusions from this research may illustrate how varying degrees of management-derived social change impacts in-herd EEHV epidemiology, and the risk associated with recrudescent cases to susceptible individuals. These findings may additionally inform EEHV-HD prevention and control strategies by determining which management actions are appropriate when at-risk individuals are present.

\section{Materials and Methods}

\subsection{Study Animals}

Five adults from a herd of six Asian elephants at an EAZA-accredited UK zoo (1 breeding bull, 4 adult cows, 1 unsampled juvenile cow) provided a total of 165 samples. This herd had previously endured six EEHV viraemias in calves: four fatal HD cases (three from EEHV 1a and one from EEHV 1b) and two surviving EEHV 1a. All adults previously tested positive for EEHV 1a and 4 shedding; therefore, all research participants are considered EEHV 1a and 4 carriers. At the conclusion of swab collections, the Bull was 14, Cow 1 was 12, Cow 2 was 22, and both Cows 3 and 4 were 39 years old. Cow 3 is the dam of Cow 1. Cow 1 was pregnant eight months prior to the 2019 disease screening period, but there were complications, and the calf only survived a few days. Cow 2 was due to give birth in October 2019, but labour did not progress and the foetus was retained. The bull was born at a German zoo and was later transferred to a bachelor herd at a Belgian zoo, both of which were EAZA member institutions. Cow 2 was born at a different EAZA-accredited UK-based facility. Cows 3 and 4 originated from Myanmar. Management diaries were also consulted to identify any other potentially stressful events that could be associated with shedding, such as conspecific aggression, training or veterinary procedures.

\subsection{Sample Collection}

Samples were collected twice weekly throughout two three-month annual virus screening periods. Eight conjunctival and 157 trunk swabs were obtained as previously described adhering to EAZA protocols $[31,44,45]$, and stored frozen $\left(-20^{\circ} \mathrm{C}\right)$ [39]. Samples were 
transported from the UK zoo to the Royal Veterinary College (Royal College Street, London, UK) for DNA extractions, and subsequently shipped overnight to the Animal and Plant Health Agency-Weybridge (APHA, Woodham Lane, New Haw, Addlestone, Surrey, UK) for PCR.

\subsection{Viral Analysis}

\subsubsection{DNA Extraction}

DNA extractions were performed at the Royal Veterinary College with the commercial QIAGEN DNeasy ${ }^{\mathrm{TM}}$ Blood and Tissue Kit (QIAGEN Inc., Hilden, Germany). Swabs were prepared according to Dastjerdi et al. (2016) with one modification: rather than using glass beads (due to a lack of availability), an additional three-minute centrifugation at $6000 \times g$ occurred following acclimation to room temperature [31]. DNA extractions adhered to the protocol described by Hardman et al. (2012) [6]. A spectrophotometer (DS-11 FX+, DeNovix Inc, Wilmington, DE, USA) measured DNA concentrations and absorption profiles $(260 / 280 \mathrm{~nm}$ and $260 / 230 \mathrm{~nm})$ to ensure extraction success. Products were transferred to sterile $96-$ well plates, sealed and stored at $-20^{\circ} \mathrm{C}$.

\subsubsection{Quantitative PCR (qPCR)}

Quantitative PCRs were conducted at APHA-Weybridge with the QIAGEN QuantiFast Pathogen + IC Kit ${ }^{\mathrm{TM}}$ (QIAGEN Inc., Hilden, Germany) as described by Dastjerdi et al. (2016) and cycling conditions of $95^{\circ} \mathrm{C}$ for $5 \mathrm{~min}$ followed by 43 cycles of $95^{\circ} \mathrm{C}$ for $15 \mathrm{~s}$ and $60^{\circ} \mathrm{C}$ for $30 \mathrm{~s}$ [31]. Each sample was extracted and tested once alongside a negative extraction control (EEHV negative DNA extract), a no-template control (140 $\mu \mathrm{L}$ water), and positive template control (PTC, HPLC purified 100 base synthetic oligonucleotides purchased from Eurofins Genomics, Wolverhampton, UK). The relevant primers, hydrolysis probes, and PTCs were used to detect EEHV 1a/b [30], 4a/b [46], and the alpha-gene of the translation elongation factor protein $(\mathrm{EF}-1-\alpha)$ (Table 1). A valid assay produced a FAM fluorescence signal for the PTC and no signal for the negative and no-template controls. Cycle thresholds $(\mathrm{Ct})$ of $\leq 43$ were accepted as EEHV $1 \mathrm{a} / \mathrm{b}, 4 \mathrm{a} / \mathrm{b}$ and EF-1- $\alpha$ positive. Detection of the housekeeping gene EF-1- $\alpha$ confirms DNA extraction and $\mathrm{qPCR}$ performance $[26,47]$. If EF-1- $\alpha$ was not detected, results were considered inconclusive and excluded from further analysis. This study omitted qPCR analysis for EEHV $5 \mathrm{a} / \mathrm{b}$ due to lack of a validated PCR.

Table 1. Primers, hydrolysis probes and PTCs employed to detect EEHV 4a/b [46], and EF-1- $\alpha$. EEHV 1a/b primers and probes were from Stanton et al. (2010) [30].

\begin{tabular}{lll}
\hline & Forward primer & $5^{\prime}$-GAT CCA CAA GGA GTT CGG-3' \\
\hline & Reverse primer & $5^{\prime}$-GTC CGT GAT ATT TAC GTK ACT-3 \\
\hline \multirow{2}{*}{ EEHV 4a/b } & Hydrolysis probe & $\begin{array}{l}5^{\prime} \text {-[FAM] AAT AGT CGC CAC GTC TCC ATG } \\
{[\text { MGBEQ]-3' }}\end{array}$ \\
\hline & & $5^{\prime}$-CGC AGG TGC GCA CGA TCC ACA AGG AGT TCG \\
& PGC & GGG ACA GTC ACG TAA ATA TCA CGG ACG TGG \\
& & CCA GCA A-3' \\
\hline EF-1- $\alpha$ & Forward primer & $5^{\prime}$-CCA CAT CAA CAT CGT CGT C-3' \\
\hline \multirow{2}{*}{ Reverse primer } & $5^{\prime}$-TTC CCA TCT CAG CAG CTT C-3' \\
\hline \multirow{2}{*}{ Hydrolysis probe } & $5^{\prime}$-[FAM] AGT CCA CCA CTA CTG GTC ACC TGA TCT \\
& ACA A [BHQ1]-3' \\
\hline
\end{tabular}

\subsubsection{Data Normalisation}

By employing a portion of the method described by Pfaffl (2001), various samples can be compared via normalising EEHV shedding to EF-1- $\alpha$ gene expression $[48,49]$ :

$$
\text { Normalised shedding }=\Delta \mathrm{Ct}=\mathrm{Ct} \text { EEHV } 1 \mathrm{a} / \mathrm{b} \text { or } 4 \mathrm{a} / \mathrm{b}-\mathrm{Ct} \text { EF-1- } \alpha
$$


Normalised shedding allows equal interpretation of results across facilities, experimental settings, and sample types [49]. Cts describe the number of qPCR cycles necessary to detect primer-specific DNA; therefore, samples producing higher $\mathrm{Cts}$ possess less target DNA and, accordingly, higher $\triangle \mathrm{Ct}$ results indicate less EEHV shedding [6]. Figures visualising normalised shedding accordingly display inverted y-axes to describe this relationship.

\subsection{Management Periods}

Management actions were categorised into periods of social change (between and within herd moves) and social stability, which served as a control (Figure 1). 'Between herd moves' describes relocating two bulls out of the collection, three days later importing a new bull (auditory and olfactory contact only), and 19 days later allowing barrier-protected exposure (restricted trunk contact with the herd). 'Within herd moves' represents mixing the novel elephant with the cow herd for breeding purposes (i.e., unrestricted direct contact). To evaluate the effects of social change on EEHV recrudescence, samples were assigned to a management period. Any sample collected after a management event could reveal residual effects, so all dates after an event were designated within the same management period. Although the period of social stability commenced 11 months after the period of between herd moves, a lack of continuous shedding in this timeframe indicated its suitability as a control. Between herd moves encompassed 85 samples, eight of which were conjunctival swabs, whilst within herd moves and social stability management periods only contained trunk swabs ( $n=55$ for within, $n=25$ for social stability).

\section{October 2019 \\ $\begin{array}{llllll}1 & 2 & 3 & 4 & 5 & 6\end{array}$ \\ $\begin{array}{lllllll}7 & 8 & 9 & 10 & 11 & 12 & 13\end{array}$ \\ 14151617181920 \\ $\begin{array}{lllllll}21 & 22 & 23 & 24 & 25 & 26 & 27\end{array}$ \\ 28 (29)(30) 31}

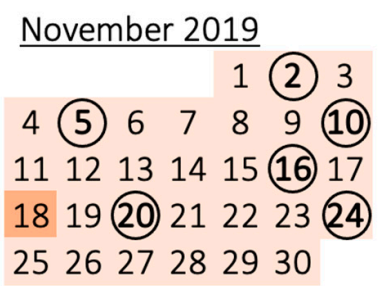

November 2020

$\begin{array}{llll}1 & 2 & 3 & 4\end{array}$

$\begin{array}{lllllll}5 & 6 & 7 & 8 & 9 & 10 & 11\end{array}$

(12) $13 \quad 141516$ (17) 18

(19)(20) 2122232425

(26) 2728 (29) 3031

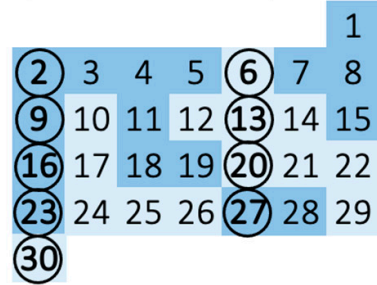

December 2019

(30) 31

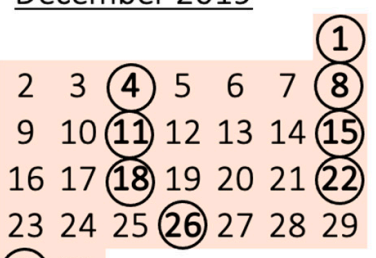

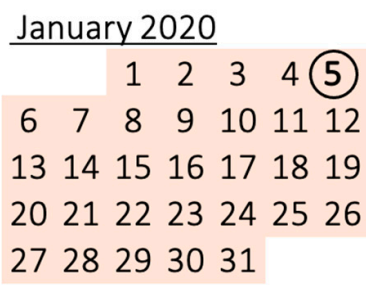

Key

Between herd move events

Between herd moves period

Within herd move events Within herd moves period

Sample collection
Figure 1. Calendar of the two virus screening periods, illustrating the dates of sample collection and management events. Circled dates describe sample collection from five elephants-except, in the case of consecutive dates (19-20 October 2020 and 4-5 December 2020), at which times the four cows were swabbed the first day and the bull was swabbed the second. Two bulls were moved away on 25 October 2019, a new bull moved into his respective enclosure on 28 October 2019, and tactile contact through a barrier was allowed with the cows after 18 November 2019; hence, samples collected from 30 October 2019 to 5 January 2020 were assigned as the 'between herd moves' period. Direct mingling for breeding took place throughout November 2020; thus, samples from 2 November 2020 to 7 December 2020 were designated as the 'within herd moves' period. The control period of social stability occurred throughout October 2020. 'Social change' represents the between and within herd moves management periods.

\subsection{Statistical Analysis}

The following statistics were performed in $\mathrm{R}(\mathrm{v}$ 4.0.3) and results were deemed significant at an $\alpha$-value of $p<0.1$ due to the sample size. EF-1- $\alpha$ Cts and normalised EEHV 
shedding $(\Delta \mathrm{Ct})$ distributions were evaluated for normality using a histogram, normal $\mathrm{Q}-\mathrm{Q}$ plot and Shapiro-Wilk test. Outliers were identified using box plots. Generalised estimating equations (GEE), designed specifically for longitudinal studies, were used to evaluate the effects of management periods on EEHV status (whether an elephant is negative or positive, i.e., exhibiting a Ct below 43) [50]. Exchangeable working correlation matrices accounted for repeated measures within the elephant and sample types were treated equally. Results were presented as odds ratios (OR) with $95 \%$ confidence intervals (CI). Sample type and elephant ID served as predictors for EEHV status in a GEE before assessing the odds of EEHV shedding associated with various management periods. If this GEE indicated sample type and elephant ID did not influence EEHV status, the elephant characteristics, management diary notes, and DNA extraction absorption profiles were cross-referenced to speculate on the aetiology of any insignificant shedding anomalies.

A GEE for EEHV status (using a binomial family distribution) determined whether social change influenced the odds of testing positive for EEHV relative to the control period in October 2020. A GEE (using a Gaussian family distribution) identified any differences in EEHV shedding (i.e., normalised shedding, $\Delta \mathrm{Ct}$ ) during periods of social change compared to social stability. Results were presented as estimates with associated standard errors, and residuals were evaluated for normality to confirm model assumptions. To isolate the individual effects of between and within herd moves, these two GEEs were repeated, and a post hoc Tukey test revealed which posed the strongest influence on EEHV status.

To evaluate whether recrudescent cases exhibit a similar delay to those of primary infections $[31,51]$ in the commencement of shedding following social change, samples collected within a week of the first event were excluded (i.e., 30 October 2019, 2 November 2019, 2 November 2020, 6 November 2020). A GEE analysing the effect on EEHV status was repeated, where any relative increase in the odds of testing positive was considered attributable to a one-week delay in shedding onset.

\section{Results}

\subsection{DNA Extraction and $q P C R$ Normalisation}

DNA extractions were successful for all samples $(n=165)$ and all extractions yielded sufficient DNA for qPCR, as determined by the spectrophotometer. Housekeeping gene EF-1- $\alpha$ was identified in all extractions, indicating samples contained elephant DNA and lacked PCR inhibitors (Figure 2). The average EF-1- $\alpha$ and EEHV 1a/b PTC Cts were 31.32 and 28.22 respectively; samples deviating below or above this threshold were controlled for via the use of Pfaffl's (2001) $\Delta$ Ct normalisation method. Although EF-1- $\alpha$ Cts ranged considerably (range Cts $=24.25-42.46$ ) and the data failed the Shapiro-Wilk test $(p<0.001)$, the histogram and Q-Q plot appeared normal (Figure A1). There were no trends suggesting shipping jeopardised sample integrity. Six EF-1- $\alpha$ Cts were outliers; however, five of these had undetectable levels of EEHV and, thus, did not influence GEE analyses. The remaining EF-1- $\alpha$ outlier $(26.63 \mathrm{Cts}$ ) was detected from a sample provided by Cow 4 during between herd moves (2 November 2019), which identified EEHV 1a/b (37 Cts). All samples were included in subsequent analyses; normalisation eliminated all outliers and $\Delta \mathrm{Ct}$ data exhibited a normal distribution (Shapiro-Wilk $p=0.89$ ) (Figure A2).

\subsection{Shedding Events and Confounding Variables}

Sixteen EEHV 1a/b shedding events were identified, but none was positive for EEHV $4 \mathrm{a} / \mathrm{b}$ (Figure 3). No samples were identified to have more than one EEHV genotype. Neither elephant ID (Bull $p=0.70$, Cow $1 p=0.196$, Cow $2 p=0.72$, Cow $3 p=0.69$, Cow 4 $p=0.69$ ) nor sample type (conjunctival swabs $p=0.571$, trunk swabs $p=0.313$ ) significantly influenced the odds of testing positive for EEHV. Only one positive sample (collected from Cow 2) was detected throughout social stability, indicating no elephant was a continuous shedder and, thus, this period served as a suitable control. Two (Cow 4's 2 November 2019; Bull's 18 December 2019) and four (Cow 3's 20 and 23 November 2020; Cow 4's 13 and 
16 November 2020) samples collected during between and within herd moves, respectively, did not coincide with other management events (Table 2).

\begin{tabular}{|c|c|c|c|}
\hline \multicolumn{4}{|c|}{ Key (EF-1-a qPCR Ct results) } \\
\hline & & Mean Ct & Range Cts \\
\hline & Conjunctival swab & 26.80 & $24.25-30.34$ \\
\hline & Trunk swab & 33.14 & $27.57-42.46$ \\
\hline & No sample taken & & \\
\hline \multirow[t]{3}{*}{ - } & Social stability (control) & 33.67 & 29.70-38.43 \\
\hline & Between herd moves & 32.31 & $24.25-42.46$ \\
\hline & Within herd moves & 33.14 & $28.05-38.07$ \\
\hline
\end{tabular}

\begin{tabular}{|c|c|c|c|c|c|c|}
\hline date & Cow1 & Cow2 & Cow3 & Cow4 & Bull & Mgmt context \\
\hline $30 / 10 / 2019$ & 40.82 & 34.41 & 28.17 & 32.00 & 28.77 & \\
\hline $02 / 11 / 2019$ & 35.18 & 31.39 & 30.80 & 26.63 & 34.16 & \\
\hline 05/11/2019 & 26.17 & 24.25 & 26.97 & 31.38 & 30.60 & \\
\hline $10 / 11 / 2019$ & 42.46 & 33.42 & 31.18 & 31.15 & 34.22 & \\
\hline $16 / 11 / 2019$ & 35.13 & 36.61 & 35.79 & 31.05 & 31.33 & \\
\hline $20 / 11 / 2019$ & 33.90 & 37.66 & 33.55 & 32.30 & 34.41 & \\
\hline $24 / 11 / 2019$ & 32.02 & 34.66 & 33.56 & 35.21 & 35.78 & \\
\hline $01 / 12 / 2019$ & 34.43 & 32.31 & 35.26 & 33.24 & 31.19 & \\
\hline $04 / 12 / 2019$ & 32.80 & 33.85 & 32.04 & 30.64 & 33.05 & \\
\hline $08 / 12 / 2019$ & 30.32 & 33.07 & 32.01 & 30.46 & 32.58 & \\
\hline $11 / 12 / 2019$ & 26.96 & 25.83 & 30.34 & 30.40 & 34.52 & \\
\hline $15 / 12 / 2019$ & 33.51 & 27.57 & 31.20 & 30.76 & 35.78 & \\
\hline $18 / 12 / 2019$ & 33.70 & 32.08 & 33.48 & 31.09 & 28.30 & \\
\hline $22 / 12 / 2019$ & 33.14 & 30.76 & 33.10 & 34.06 & 34.82 & \\
\hline $26 / 12 / 2019$ & 34.63 & 32.76 & 32.06 & 29.56 & 34.13 & \\
\hline $30 / 12 / 2019$ & 33.53 & 33.23 & 31.70 & 29.74 & 29.63 & \\
\hline 05/01/2020 & 34.55 & 27.28 & 33.46 & 32.56 & 32.00 & \\
\hline $12 / 10 / 2020$ & 34.91 & 36.16 & 31.05 & 34.13 & 33.65 & - \\
\hline $17 / 10 / 2020$ & 36.75 & 32.01 & 32.83 & 34.35 & 34.40 & - \\
\hline $19 / 10 / 2020$ & 30.22 & 33.81 & 36.13 & 31.91 & & - \\
\hline $20 / 10 / 2020$ & & & & & 33.98 & - \\
\hline $26 / 10 / 2020$ & 33.40 & 35.13 & 31.19 & 32.19 & 35.00 & - \\
\hline $29 / 10 / 2020$ & 37.05 & 38.43 & 31.06 & 29.70 & 32.41 & - \\
\hline $02 / 11 / 2020$ & 35.97 & 33.10 & 32.09 & 32.01 & 35.64 & \\
\hline $06 / 11 / 2020$ & 34.19 & 33.87 & 32.47 & 33.89 & 28.05 & \\
\hline $09 / 11 / 2020$ & 34.62 & 33.66 & 32.02 & 32.60 & 32.47 & \\
\hline $13 / 11 / 2020$ & 32.89 & 33.62 & 32.81 & 32.09 & 29.66 & \\
\hline $16 / 11 / 2020$ & 33.47 & 33.08 & 34.07 & 32.90 & 32.87 & \\
\hline $20 / 11 / 2020$ & 34.14 & 38.07 & 32.43 & 33.04 & 37.72 & \\
\hline $23 / 11 / 2020$ & 33.21 & 33.72 & 33.06 & 32.92 & 35.04 & \\
\hline $27 / 11 / 2020$ & 35.25 & 31.07 & 35.17 & 35.55 & 35.50 & \\
\hline $30 / 11 / 2020$ & 35.23 & 32.12 & 30.92 & 31.62 & 30.18 & \\
\hline $04 / 12 / 2020$ & 33.67 & 31.71 & 33.30 & 31.28 & & \\
\hline $05 / 12 / 2020$ & & & & & 32.15 & \\
\hline $07 / 12 / 2020$ & 32.44 & 29.80 & 31.03 & 34.24 & 33.06 & \\
\hline Total samples & 33 & 33 & 33 & 33 & 33 & \\
\hline Mean Ct & 33.93 & 32.75 & 32.33 & 32.05 & 32.94 & \\
\hline Ct min & 26.17 & 24.25 & 26.97 & 26.63 & 28.05 & \\
\hline Ct max & 42.46 & 38.43 & 36.13 & 35.55 & 37.72 & \\
\hline
\end{tabular}

Figure 2. Heatmap of the housekeeping gene (EF-1- $\alpha)$ qPCR results. All samples had a detectable level of EF-1- $\alpha$ and, therefore, no samples were excluded from statistical analyses. 


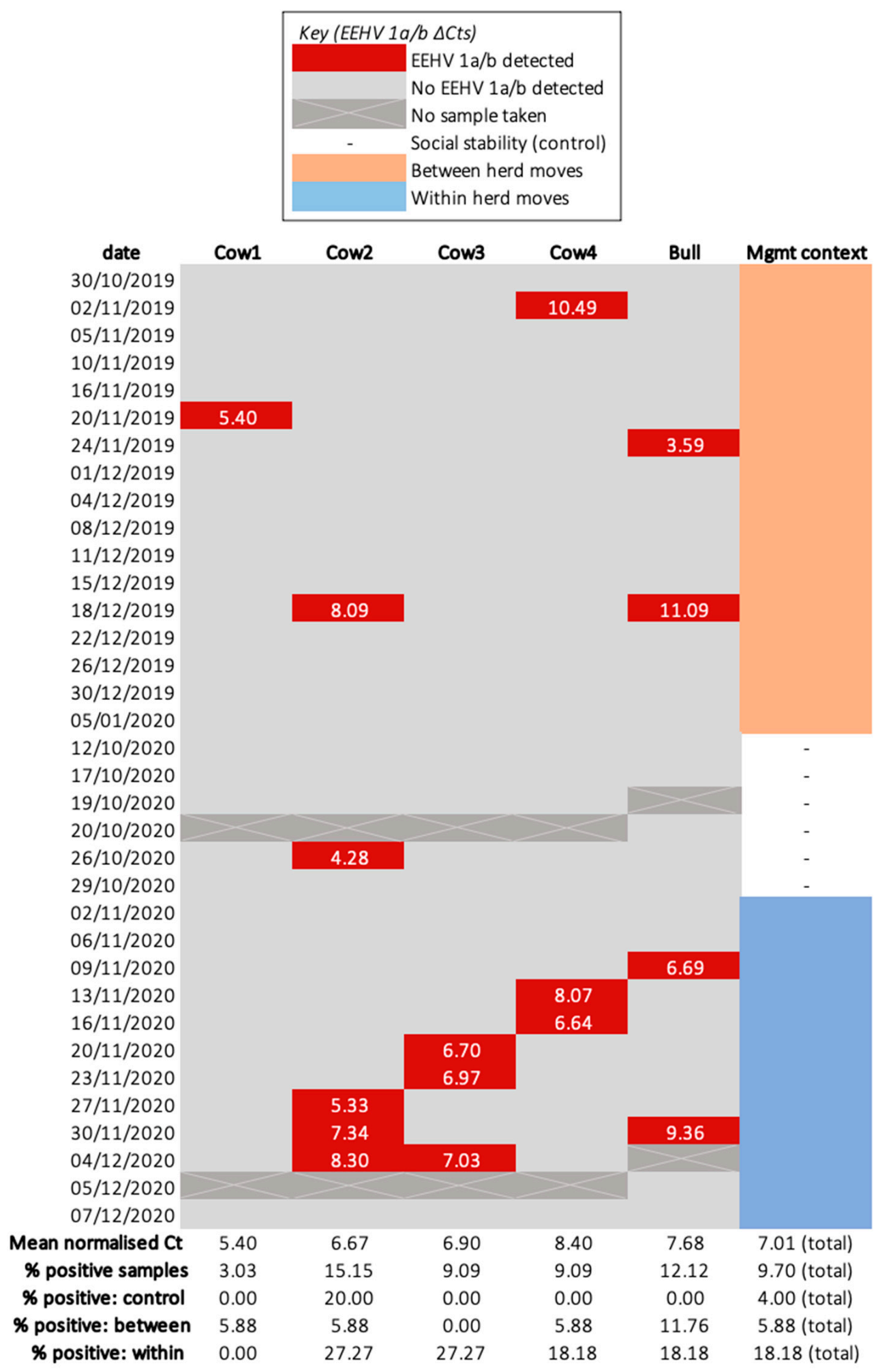

Figure 3. Heatmap of normalised EEHV $1 \mathrm{a} / \mathrm{b}$ shedding $(\Delta \mathrm{Ct})$ for each sampled elephant. The percentage of samples exhibiting an EEHV $1 \mathrm{a} / \mathrm{b}$ and EF-1- $\alpha$ Ct below 43 is indicated within the "\% positive" rows for each individual elephant and the total herd. This value was calculated by dividing the quantity of samples possessing EEHV $1 \mathrm{a} / \mathrm{b}$ by the total number collected within the corresponding period and multiplying by 100 . 
Table 2. A list of notable management events occurring throughout the study period which may have influenced EEHV recrudescence. Data was extracted from keeper management diaries to identify a broad correlation with other management events coinciding with shedding. Weekly foot care and training (operant and desensitisation) occurred for each elephant throughout every management period. Veterinary procedures, such as blood draws and injections, also frequently took place during non-excretory periods. Days until the next shedding are presented in order of elephant ID, where "-" indicates no EEHV was detected after the management event within the appropriate period.

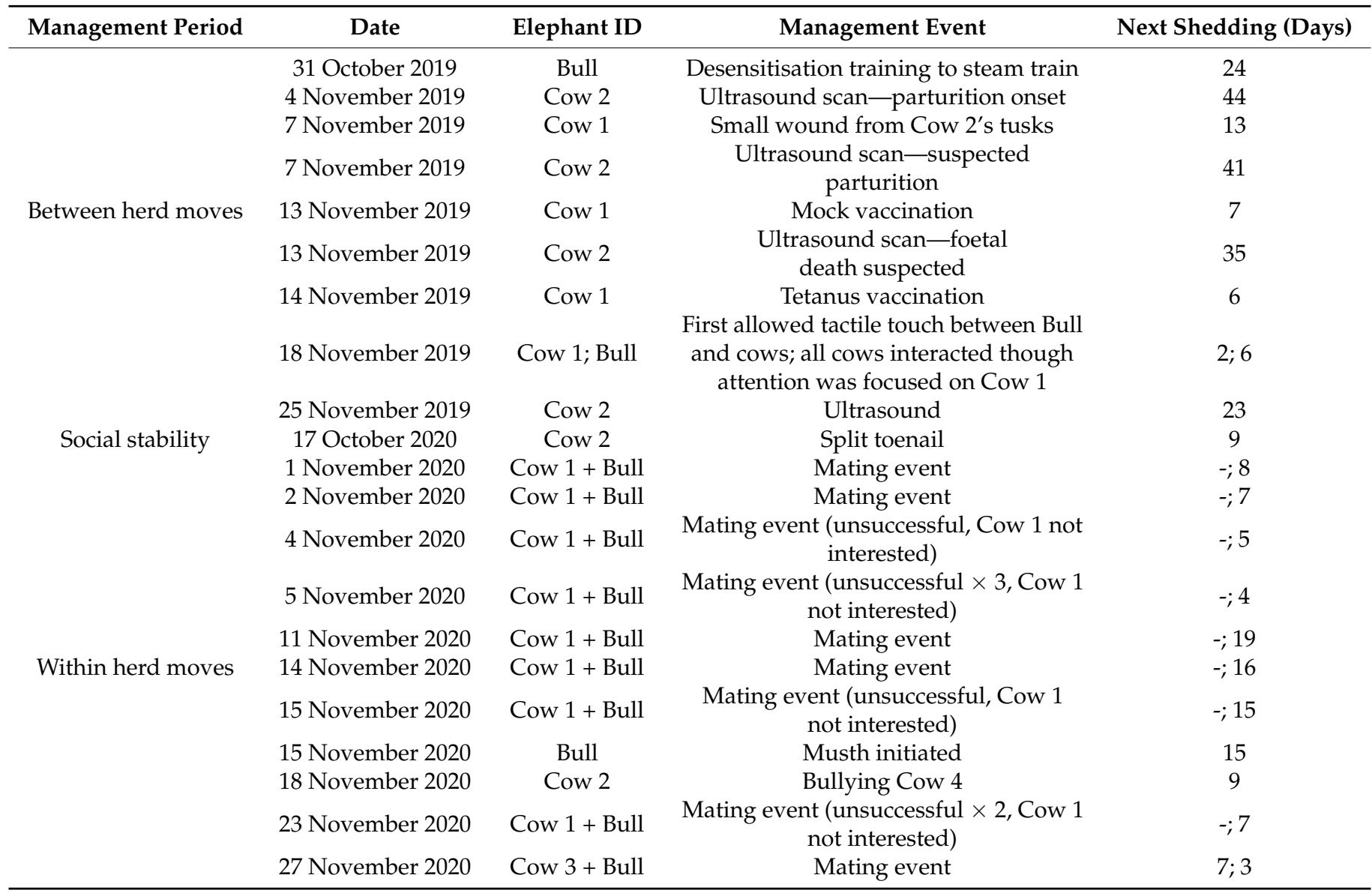

\subsection{The Influence of Social Change on the Odds of EEHV Recrudescence and Shedding Load for} Individual Elephants

The period of social change demonstrated fifteen EEHV 1a/b shedding events, while the control period encompassed one. Social change increased the odds of testing positive for EEHV 1a/b relative to social stability; however, the effect was not significant $(\mathrm{OR}=2.88$, $95 \% \mathrm{CI}=0.363-22.8, p=0.317)$. Compared to the singular positive sample collected during the control period, those obtained throughout social change exhibited significantly less viral DNA loads per sample $\left(+3.119 \Delta \mathrm{Cts} \pm 0.483, p=1.1 \times 10^{-10}\right)$. Residuals were normally distributed, confirming model fit (Shapiro-Wilk test $p=0.8$ ) (Figure A3).

3.4. The Respective Effects of between and within Herd Moves on the Odds of EEHV Recrudescence and Shedding Load for Individual Elephants

Between and within herd moves encompassed five and ten EEHV 1a/b shedding events, respectively. Though the influence was not significant, between and within herd moves were associated with an increase in EEHV $1 \mathrm{a} / \mathrm{b}$ detection odds compared to social stability (between herd moves $\mathrm{OR}=1.5,95 \% \mathrm{CI}=0.167-13.5, p=0.717$; within herd moves $\mathrm{OR}=5.33,95 \% \mathrm{CI}=0.644-44.2, p=0.121)$. Between and within herd moves also exhibited significantly higher Cts, and, therefore, lower viral DNA loads per sample, relative to the singular positive control (between herd moves $+3.44 \Delta \mathrm{Cts} \pm 1.28 p=0.0074$; within 
herd moves $\left.+2.95 \Delta \mathrm{Cts} \pm 0.311 p<2 \times 10^{-16}\right)$. Residuals were normally distributed (Shapiro-Wilk test $p=0.8$ ) (Figure A3). Between herd moves demonstrated the lowest mean normalised EEHV DNA load among all management periods and shedding was most common throughout within herd moves (18.18\% of samples were positive) (Figure 4 ). This trend was reflected in the post hoc analysis, which revealed within herd moves imposed a significantly stronger influence on EEHV status compared to between herd moves $(p=0.0425)$.

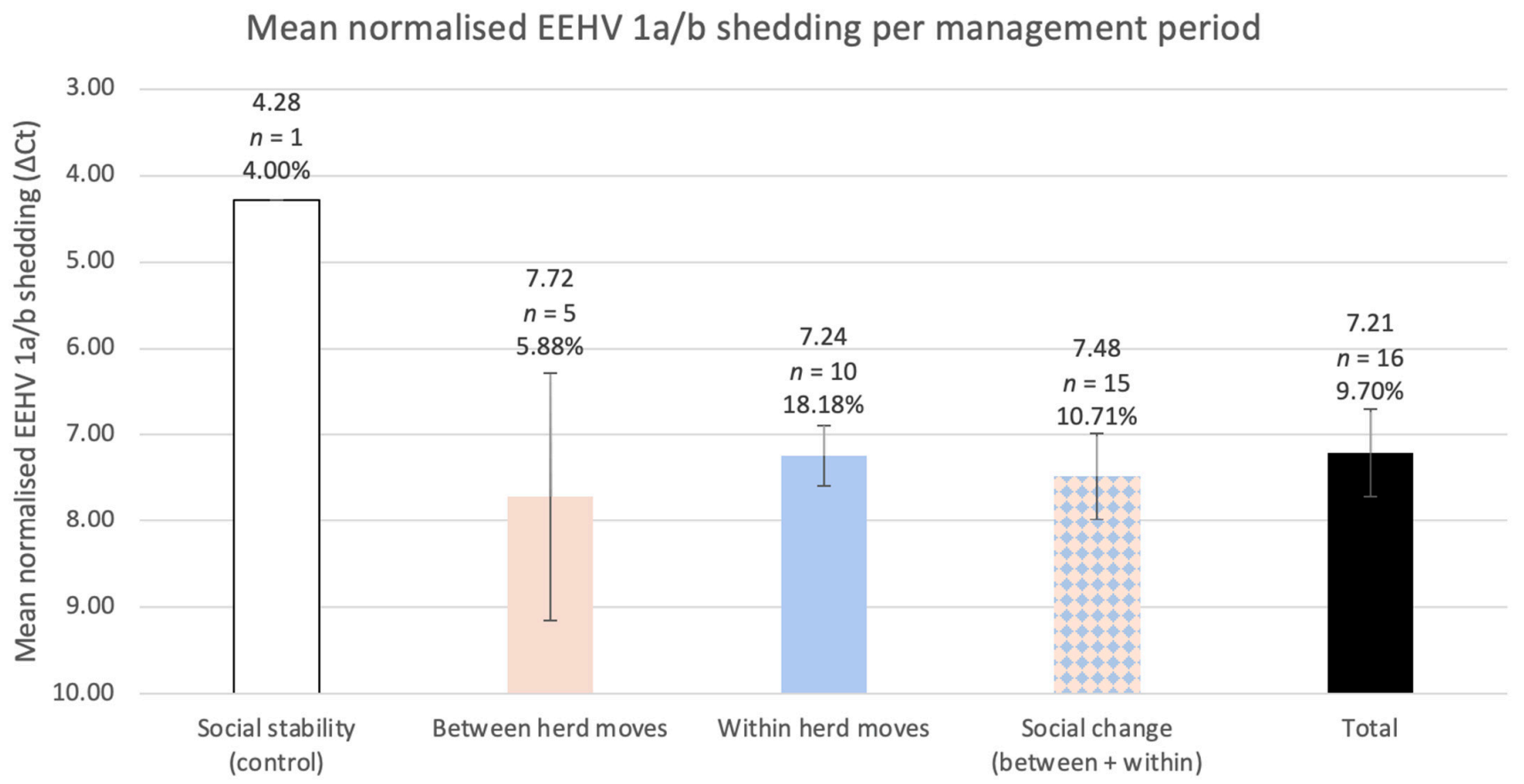

Figure 4. The study herd's mean normalised EEHV 1a/b DNA load for each management period, with corresponding error bars (95\% confidence intervals). The percentage of positive samples is listed below each sample size and was calculated identically to those in Figure 3. Low Cts represent higher viral DNA, therefore, the $\mathrm{y}$-axis is inverted to visualise the relationship between $\Delta \mathrm{Ct}$ (normalised shedding) and the relative viral DNA. GEEs informed by normalised shedding revealed significantly less viral DNA per sample within all social change periods compared to the singular positive control sample (social change $p=1.1 \times 10^{-10}$; between herd moves $p=0.0074$; within herd moves $\left.p<2 \times 10^{-16}\right)$.

\subsection{Characteristics of Recrudescent Viral Shedding}

Samples obtained within the first week of a social change period may have been reflective of previous, rather than current, management. When excluding the first week of each period, the odds of EEHV recrudescence increased for all social change management periods and revealed a significant influence from within herd moves (social change $\mathrm{OR}=3.27,95 \% \mathrm{CI}=0.412-26, p=0.262$; between herd moves $\mathrm{OR}=1.6,95 \% \mathrm{CI}=0.178-14.4$, $p=0.675$; within herd moves $\mathrm{OR}=6.86,95 \% \mathrm{CI}=0.823-57.1, p=0.0751)$. The swiftest EEHV $1 \mathrm{a} / \mathrm{b}$ shedding onset for both between and within herd moves occurred after eight days (Figure 5). Cow 2 appeared to shed most frequently, providing five positive samples throughout the study, while Cow 1 shed once. Most shedding events were singular; continuous shedding (meaning consecutive positive samples) occurred three times and only during within herd moves, the longest being a week from Cow 2 . Two consecutive shedding events successively decreased viral loads with time, yet Cow 4 exhibited an inverse response and peaked viral shedding two weeks after the first within herd move. 


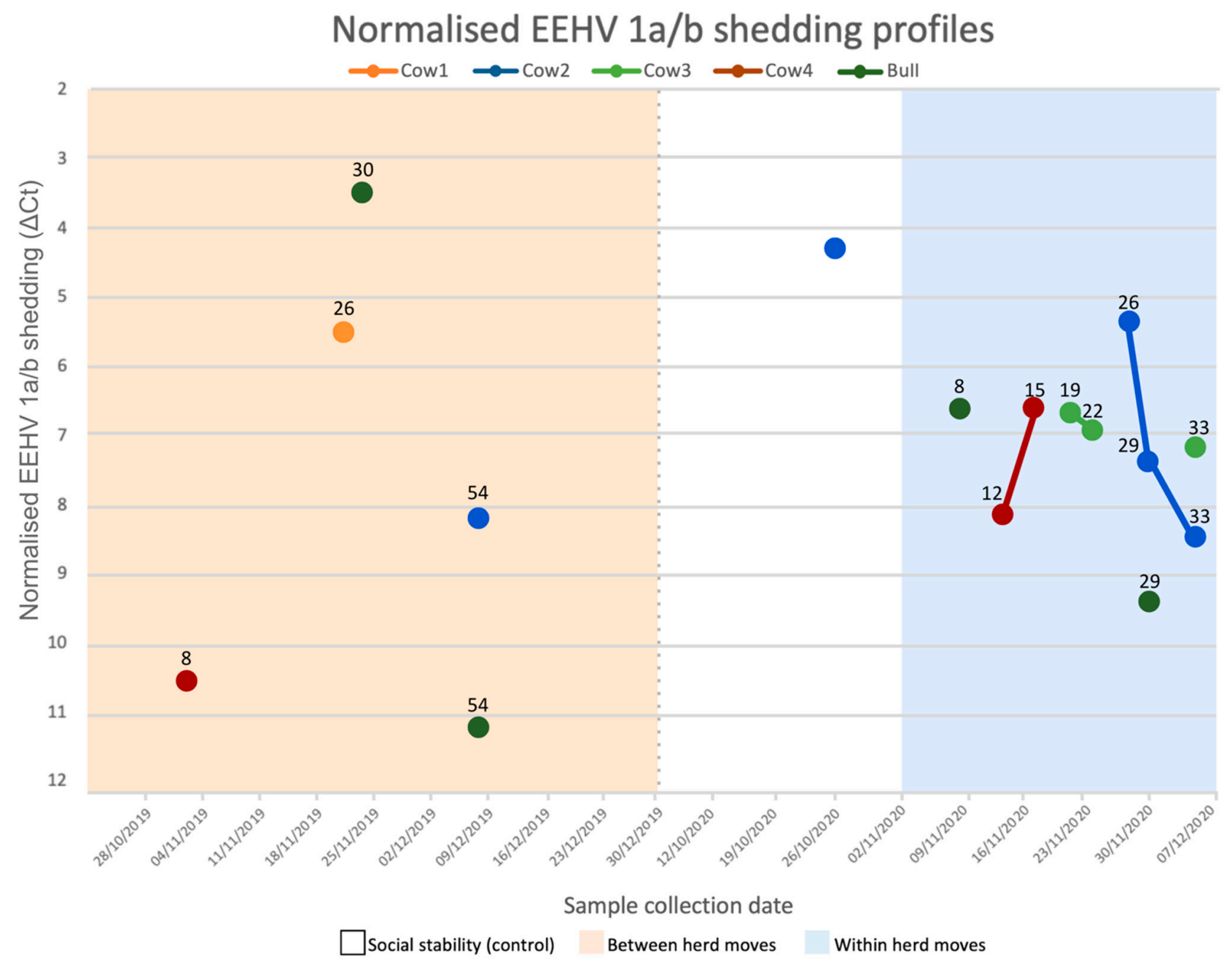

Figure 5. EEHV 1a/b normalised shedding profiles for each sampled Asian elephant. Values above each data point indicate the number of days post the first management event (i.e., 25 November 2019 for between herd moves and 1 November 2020 for within herd moves). Samples that are joined by a line were collected over sequential sampling dates. The y-axis is flipped to appropriately represent the inverse relationship between $\Delta \mathrm{Ct}$ (normalised shedding) and relative viral DNA loads, as low $\Delta$ Cts represent high viral DNA. Sample collection dates are listed by week, beginning on Mondays. The dotted grey line indicates a 10-month separation between periods. Tactile touch behind a barrier was allowed following 18 November 2019. This shedding profile describes positive EEHV samples only. Elephants did not present detectable EEHV 1a/b nor 4a/b DNA at all other sampling points.

\section{Discussion}

To the authors' knowledge, this is the first longitudinal study examining the independent effects of between and within herd moves on EEHV recrudescence. All management periods were associated with increased odds of detectable EEHV $1 \mathrm{a} / \mathrm{b}$, however, only the effect of within herd moves was statistically significant $(\mathrm{OR}=6.86,95 \% \mathrm{CI}=0.823-57.1$, $p=0.0751$, post hoc $p=0.0425$ ). Both management periods could potentially increase clinical HD risk via inverse effects: between herd moves elevate the chance of one-off exposure to a high viral load or a new virus genotype, whilst within herd moves could promote herd-wide EEHV recrudescence, increasing overall background but manageable viral load exposure. From an epidemiological perspective, these findings suggest that exposure to new elephants and novel mixing should be considered as EEHV exposure risks to susceptible elephants, if present. 
There are several limitations associated with this study. As EEHV $1 \mathrm{a}$ and $1 \mathrm{~b}$ are indistinguishable by this qPCR, co-infections may have been concealed or consecutive shedding events may have encompassed sequential infections [24,30,52]. Four of five sampled elephants had previously resided elsewhere; relocation can expose elephants to novel strains [12,13], increasing the odds of co-infection. A larger sample size would have been preferable to establish a credible control baseline or equivalent sample sizes among management periods. Time and resource constraints have also prevented technical qPCR replicates, limiting statistical accuracy. It is noteworthy to mention that detecting EEHV shedding onset can be influenced by the employed methods (i.e., efficiency of sampling, DNA extraction and qPCR). Unknown factors could have also promoted recrudescence; for example, a latent case in Napoli reactivated during a period of Salmonella septicaemia [53]. Taking these challenges into account, biological implications of these results remain valid.

The EF-1- $\alpha$ gene served as an internal control and host DNA was identified in all samples. For Asian elephants, although cotton swabs produce approximately three CTs higher (equivalent to 10-fold) nucleic acids than whole blood [46], because all swabs were identical, detection of host DNA proved reliable and comparable among types. The six EF-1- $\alpha$ Ct outliers may indicate some variability in sample collection; however, these did not influence inferential statistics since data normalisation was highly effective. Four of six EF-1- $\alpha$ Ct outliers arose from conjunctival swabs, though only one detected EEHV $1 \mathrm{a} / \mathrm{b}$ (Cow 4's 2 November 2019 sample); this was as expected as conjunctiva has the least cellular turnover. To ensure consistent sampling among elephants and to increase sample size, both sample types were included. However, previous research using a nearly identical DNA extraction protocol found conjunctival sampling to be more sensitive for EEHV 1a/b [6]. This relationship was reflected for EF-1- $\alpha$, as Figure 2 suggests greater sensitivity from conjunctival swabs. Nevertheless, inferential findings remain legitimate as the sample type GEE found no significant effect on EEHV detection odds [49]. Initial validation of this real time PCR was carried out by Stanton et al. (2010), in which they tested the PCR against all their EEHV-1 positive archival samples, including a case involving an EEHV1a/b chimeric genome and the test provided a positive result for all [30]. We have also compared complete DNA sequences for the Major DNA-Binding Protein (MDBP) gene, the gene to which the EEHV-1 primers and probe are designed, from those EEHV-1a and $1 \mathrm{~b}$ sequences available in the GenBank and from unpublished APHA archive. The analysis indicated a nucleotide identity of $99.2-100 \%$ for this gene, a relatively stable gene considering its vital role in virus replication. The sequences of the EEHV-1 primers and probe, however, were identical to those of the sequences analysed. Nonetheless, the potential of EEHV- 1 false negatives could not be overlooked, but their likelihood is negligeable.

EEHV $1 \mathrm{a} / \mathrm{b}$ shedding appeared to commence six days after a stressful event-one day less than previously described primary cases [31]. Three samples collected less than six days after a confounding management event detected EEHV 1a/b; however, recrudescence was likely initiated by other variables. Cow 1 started shedding EEHV $1 \mathrm{a} / \mathrm{b}$ two days after barrier-protected tactile touch with the bull (on 18 November 2019), but aggression from Cow 2 thirteen days prior, or vaccination training and injection six days prior, may also have contributed to virus reactivation and shedding [54]. The bull shed EEHV 1a/b three and four days after mating events with Cows 3 and 1, respectively. Other mating events took place beforehand, which could have equally promoted virus reactivation. It is possible that the act of mating and its associated behaviours (e.g., smelling of vulvas and urine) physically distribute EEHV among the herd [55]. Cow 3 (39 years old) shed EEHV 1a/b seven days after mating (on 27 November 2020), yet the Bull almost exclusively mixed with Cow 1 (eight mating events), who did not recrudesce during this time. Cow 3 's oestrus cycles are flatlining, so she may have been unreceptive to mating, and the resulting stress promoted EEHV $1 \mathrm{a} / \mathrm{b}$ reactivation. If future research suggests EEHV is only infectious at high viral loads, appropriate management for within herd moves could expose susceptible individuals to minimal/moderate viral loads and provide an opportunity for immunity development. Captive Asian elephant cows typically ovulate and are receptive to mating 
for two to ten days [56]. After a cow's receptive period, a bull's presence can be socially challenging and induce immunosuppression. A cost-effective and efficient suggestion to detecting a cow's follicular phase through urinary pheromones would involve presenting consistently collected cow urine samples to the bull [57]. If a bull indicates a cow is ovulating, it may prove advantageous to conduct within herd moves for one week. This could simulate in-situ mixing and allow adequate time for elephants to mate, possibly reactivate shedding of minimal viral loads, meanwhile limiting prolonged exposure.

Veterinary procedures (blood draws and ultrasounds), training (operant and desensitisation), and foot care occurred frequently during non-shedding periods and, hence did not appear to be associated with EEHV recrudescence. Previous research did not identify any associations between EEHV detection and behaviour, environment, management (e.g., sleeping activities and staff changes), or medical changes [39].

In this study, some events noted within management diaries coincided with and may have promoted reactivation. The only positive control sample, which was Cow 2's highest viral load, may have been promoted by a split toenail occurring nine days prior. Considering the GEEs comparing viral loads were relative to this single positive control sample, it would be inappropriate to conclude that social change promotes relatively lesser viral loads. Nine days prior to one of Cow 2's other shedding events (27 November 2020), conspecific aggression ensued. Additionally, Cow 2's shedding may have been influenced by her pregnancy [43]. A shedding event also occurred fifteen days after the initiation of the Bull's musth. Cow 1's tetanus vaccination may have also triggered immunosuppression and subsequently EEHV $1 \mathrm{a} / \mathrm{b}$ recrudescence. In other mammals, effective vaccines are known to be associated with a temporary period of immunosuppression [54]. Not only was this the only vaccination administered during the study period, but it also occurred exactly six days prior to Cow 1 's only shedding event (20 November 2019). If this study were to exclude all samples potentially associated with confounding variables, the effect of social change on EEHV recrudescence remains apparent: two and four positive samples would remain exclusively attributable to between and within herd moves, respectively.

These findings support the previous recrudescence trends documented by Atkins et al. (2013) and Sanchez et al. (2016), though are opposite to those in Hengtrakul et al. (2020) [39,41,42]. Both management actions incited EEHV reactivation in $80 \%$ of elephants in this study, so it is possible that external stress caused recrudescence for the entire Atkins et al. (2013) herd [41]. Inverse shedding responses occurred during within herd moves, similarly to the effect of between herd moves as described by Sanchez et al. (2016) [42]. For most events (75\%) EEHV shedding followed a decline over time. Only Cow 4 exhibited an increase in viral shedding; as the dominant female she may have been socially challenged by the Bull's presence. Hengtrakul et al. (2020) found that recrudescent EEHV in young elephants reactivated more often [39], yet in this study, the virus in the youngest cow (Cow 1, 11 years old) reactivated only once (20 November 2019), six days after her tetanus vaccination. For all other sampled elephants, the virus recrudesced on a minimum of two separate occasions. This study reveals shedding rates can vary per individual, and do not appear directly associated with age but rather novel mixing.

The aetiology of the high level of EEHV-HD mortality rates in captivity remains unknown. Some management actions, such as between herd moves, are scenarios specific to captivity. In-situ, social fluctuation and environmental olfactory cues among herds may promote constant shedding of low viral loads and therefore ample circumstances for susceptible individuals to build immunity. Management-derived social changes ex-situ may implement interactions otherwise not observed in the wild, limiting opportunity for immune system development thus elevating HD mortality risk. Haycock (2020) suggested increased frequency of fatal HD in captivity may be attributable to smaller herd sizes, since vulnerable calves are not as intermittently exposed to EEHV [26]. Herd size can affect numerous factors, including mating frequency and social interactions. The study herd is relatively small compared to free-living conspecifics, which can include over 100 individuals [58]. Research investigating the epidemiological kinetics of a larger group may reveal the 
key to developing immunity, because elevated intraspecies interactions (e.g., birth events, mixing of elephants, mating events) give rise to more opportunities for recrudescence and low-level viral exposure [1].

The findings of this study reveal several implications to captive elephant management. Management-derived social changes should be considered as EEHV exposure risks to susceptible Asian elephants. The importance of EEHV monitoring is clear and between herd movements should be avoided if a naïve individual is present within the receiving herd. Future research should focus on longitudinal, consistent sampling of multiple institutions with various herd sizes, alongside disease and external stress monitoring. Comparison of facilities with and without a history of fatal HD could also illuminate the non-viral and non-host factors attributable to EEHV mortality. It is evident, however, that between and within herd moves have epidemiological consequences, and if EEHV is to be managed appropriately, it is crucial to recognise their associated risks and proactively monitor susceptible individuals.

\section{Conclusions}

Understanding how to mitigate EEHV infections is not only a conservation, health, and welfare issue, but also a moral obligation considering the frequency of captive HD mortalities and the influence of management, as newly described by this study. Stem cell and pathophysiology research are taking place [59-62], as is experimental vaccine testing. Nevertheless, it can take years to adopt a successful captive vaccination programme and, thus, ascertaining which management actions elevate risk is necessary. Managementderived social change causes EEHV reactivation in Asian elephants. EEHV recrudescent elephants appear to commence shedding anywhere from six days to (at least) two months following between and within herd moves, which instigates close monitoring of at-risk Asian elephant calves after such events.

Author Contributions: Conceptualization, F.M.M.; methodology, S.E.T., A.D., F.M.M. and S.P.; software, S.E.T.; validation, F.M.M., S.P., and A.D.; formal analysis, S.E.T. and A.D.; investigation, S.E.T. and J.P.-W.; resources, F.M.M., A.D., and S.P.; data curation, S.E.T., J.P.-W., and A.D.; writing-original draft preparation, S.E.T.; writing—review and editing, F.M.M., S.P., and A.D.; visualisation, S.E.T.; supervision, F.M.M., S.P. and A.D.; project administration, F.M.M., S.P., and A.D.; funding acquisition, S.E.T. All authors have read and agreed to the published version of the manuscript.

Funding: This research was funded by the Aitchison-Tait Trust Wild Animal Research Scholarship at the Royal Veterinary College, University of London, the Zebra Foundation for Veterinary Zoological Education, and APHA.

Institutional Review Board Statement: Ethical review and approval were waived for this study by the University of London's Royal Veterinary College, considering samples were collected opportunistically as part of routine disease screening in accordance with the Veterinary Surgeons Act and standard EAZA protocol.

Data Availability Statement: The data presented in this study are available on request from the corresponding author, stitus20@rvc.ac.uk.

Acknowledgments: This study was carried out in fulfilment of the Wild Animal Biology MSc. degree (S.T.) at the Royal Veterinary College and the Zoological Society of London. Thank you to Biggy Simbi and Nadia Inglese for your service performing DNA extractions and qPCR. Additionally, Kathryn Perrin's and Tanja Gade's willingness to collaborate across international borders expanded the scope of the MSc dissertation in which this work was derived, and your reliability is greatly appreciated. Ruby Chang contributed imperative advice regarding statistical conceptualization and methodology. Continued support and efforts from Sophie Common, Anthony Sainsbury, and Matthew Perkins are greatly appreciated. Thank you to Carole Day, Louise Gibson, Jonathan Haycock, and Kate McVay for your guidance. The staff, keepers, and veterinarians caring for the Asian elephant herd at the Zoological Society of London's Whipsnade Zoo were essential for sample collection, transport, and care. This work would not have been possible without everyone's contributions. 
Conflicts of Interest: The authors declare no conflict of interest. The funders had no role in the design of the study; in the collection, analyses, or interpretation of data; in the writing of the manuscript; or in the decision to publish the results.

Ethics Statement: Ethical review and approval were waived for this study. Please reference the Institutional Review Board Statement for further detail.

\section{Abbreviations}

$\begin{array}{ll}\mathrm{Ct} & \text { cycle threshold } \\ \triangle \mathrm{Ct} & \text { normalised shedding (see Equation (1)) } \\ \text { EEHV } & \text { elephant endotheliotropic herpesvirus (Elephantid herpesvirus) } \\ \text { EF-1- } \alpha & \text { elongation factor protein 1, alpha gene } \\ \text { HD } & \text { haemorrhagic disease } \\ \text { RT-qPCR } & \text { real-time quantitative polymerase chain reactions }\end{array}$

Appendix A

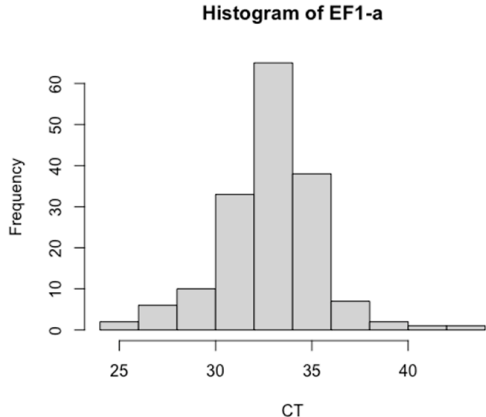

(a)

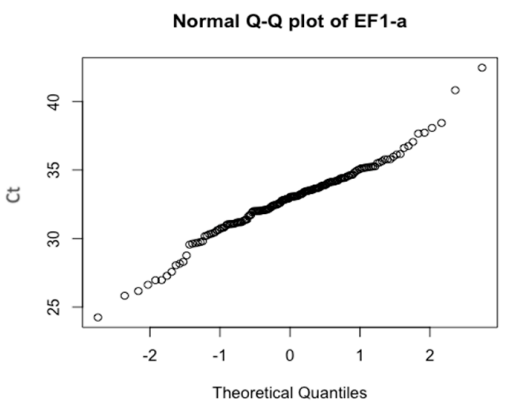

(b)

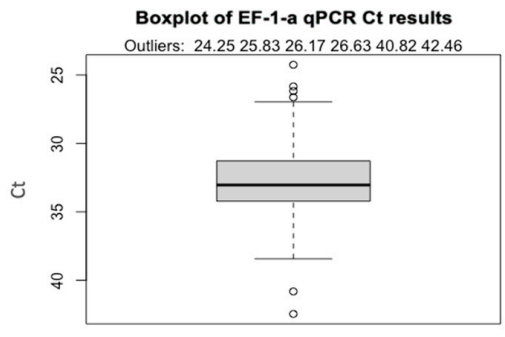

(c)

Figure A1. The (a) histogram, (b) normal Q-Q plot and, (c) box plot of EF-1- $\alpha$ Cts. Both the histogram and normal Q-Q plot exhibited an approximately normal distribution via a bell-shaped curve and alignment of data along the diagonal line, respectively. There were six EF-1- $\alpha$ outliers, one of which detected EEHV 1a/b (26.63 EF-1- $\alpha$ Cts and 37 EEHV 1a/b Cts, from Cow 4 collected on 2 November 2019). For the box plot, the y-axis is inverted to visually represent the inverse relationship between $\mathrm{qPCR}$ Cts and gene expression. As determined by a Shapiro-Wilk test, there was evidence to suggest EF-1- $\alpha$ Cts were not normally distributed $(p=0.004)$.

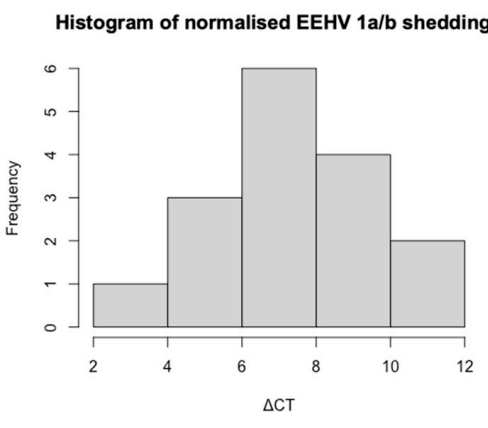

(a)

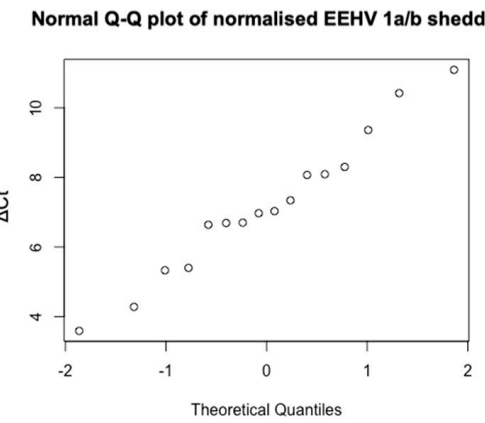

(b)
Boxplot of normalised EEHV 1a/b shedding

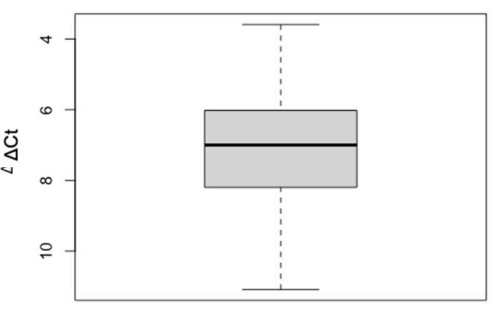

(c)

Figure A2. The (a) histogram, (b) normal Q-Q plot, and (c) box plot of the normalised EEHV $1 \mathrm{a} / \mathrm{b}$ shedding $\Delta \mathrm{Cts}$. Both the histogram and normal Q-Q plot exhibited an approximately normal distribution via a bell-shaped curve and alignment of data along the diagonal line, respectively. There were no outliers within the $\Delta \mathrm{Ct}$ dataset. For the box plot, the $\mathrm{y}$-axis is inverted to visually represent the inverse relationship between qPCR Cts and gene expression. As determined by a Shapiro-Wilk test, there was no evidence to suggest EEHV $1 \mathrm{a} / \mathrm{b} \Delta \mathrm{Cts}$ were not normal $(p=0.9)$. 


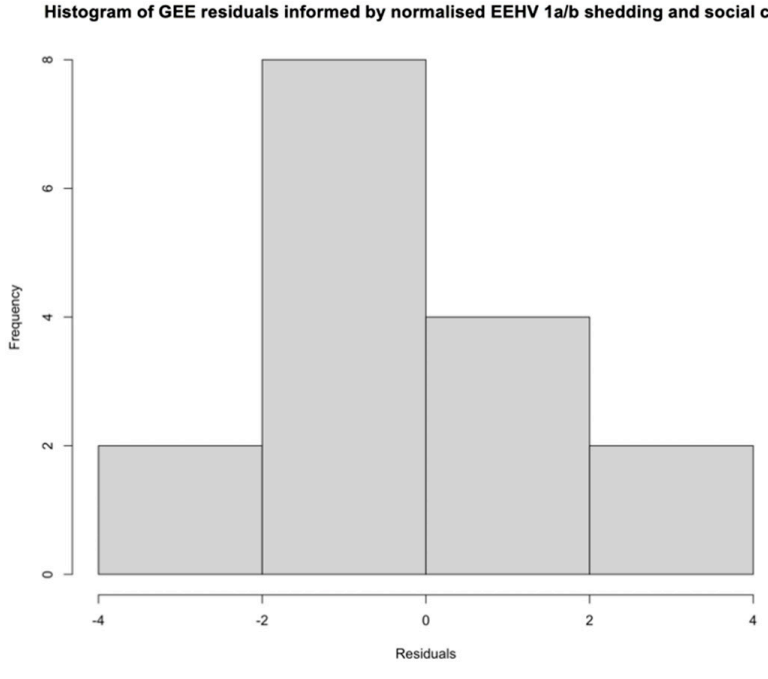

(a)

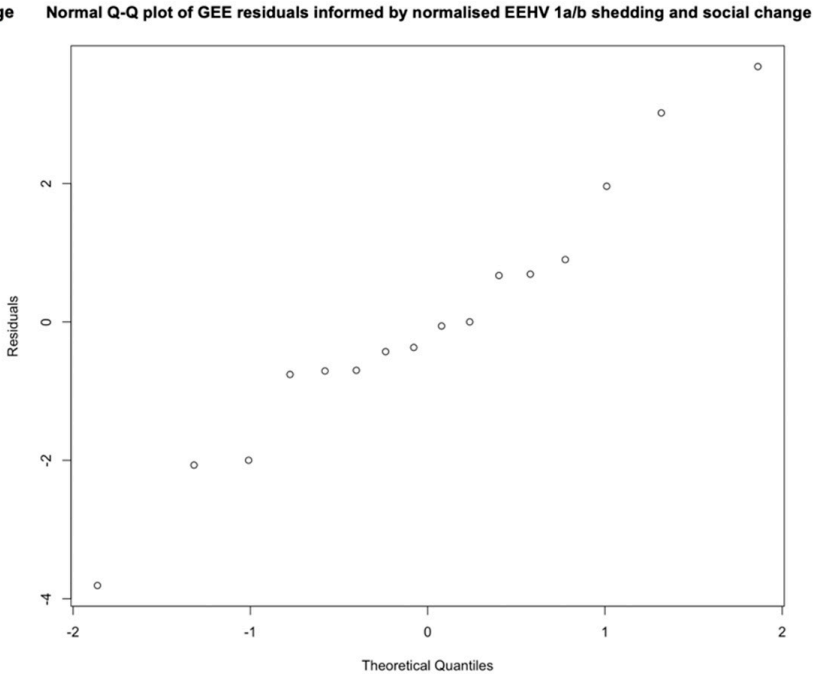

(b)

Figure A3. The (a) histogram and (b) normal Q-Q plot of GEE residuals, informed by normalised shedding $(\Delta \mathrm{Ct})$ and social change management periods. Histograms and normal $\mathrm{Q}-\mathrm{Q}$ plots for social change, between and within herd moves, were all identical as they incorporated the same data set. The histogram and Q-Q plot exhibited an approximately normal distribution via a bell-shaped curve and alignment of data along the diagonal line, respectively. There was no evidence to suggest the distributions were not normal as determined by a Shapiro-Wilk test (social change $p=0.8$, between herd moves $p=0.8$, within herd moves $p=0.8$ ).

\section{References}

1. Perrin, K.; Nielsen, S.S.; Martinussen, T.; Bertelsen, M.F. Quantification and Risk Factor Analysis of Elephant Endotheliotropic Herpesvirus-Haemorrhagic Disease Fatalities in Asian Elephants (Elephas maximus) in Europe (1985-2017). J. Zoo Aquar. Res. 2021, 9, 8-13. [CrossRef]

2. Howard, L.L.; Schaftenaar, W. Elephant endotheliotropic herpesviruses. In Fowler's Zoo and Wild Animal Medicine Current Therapy; Miller, R.E., Lamberski, N., Calle, P., Eds.; Elsevier Inc.: St. Louis, MO, USA, 2019; Volume 9, pp. 672-679. [CrossRef]

3. Hoornweg, T.E.; Schaftenaar, W.; Maurer, G.; van den Doel, P.B.; Molenaar, F.M.; Chamouard-Galante, A.; Vercammen, F.; Rutten, V.P.M.G.; de Haan, C.A.M. Elephant Endotheliotropic Herpesvirus is Omnipresent in Elephants in European Zoos and an Asian Elephant Range Country. Viruses 2021, 13, 283. [CrossRef] [PubMed]

4. Choudhury, A.; Lahiri Choudhury, D.; Desai, A.; Duckworth, J.; Easa, P. Elephas Maximus; e.T7140A12828813; The IUCN Red List of Threatened Species. 2008. Available online: https://democracy.blackpool.gov.uk/documents/s12685/The\%20IUCN\%20Red\% 20List\%20of\%20Threatened\%20Species.pdf (accessed on 16 August 2021).

5. Long, S.Y.; Latimer, E.M.; Hayward, G.S. Review of Elephant Endotheliotropic Herpesviruses and Acute Hemorrhagic Disease. ILAR J. 2016, 56, 283-296. [CrossRef] [PubMed]

6. Hardman, K.; Dastjerdi, A.; Gurrala, R.; Routh, A.; Banks, M.; Steinbach, F.; Bouts, T. Detection of Elephant Endotheliotropic Herpesvirus Type 1 in Asymptomatic Elephants Using TaqMan Real-time PCR. Vet. Rec. 2012, 170, 205. [CrossRef] [PubMed]

7. Zachariah, A.; Zong, J.-C.; Long, S.Y.; Latimer, E.M.; Heaggans, S.Y.; Richman, L.K.; Hayward, G.S. Fatal Herpesvirus Hemorrhagic Disease in Wild and Orphan Asian Elephants in Southern India. J. Wildl. Dis. 2013, 49, 381-393. [CrossRef]

8. Wiese, R.J. Asian Elephants Are Not Self-sustaining in North America. Zoo Biol. 2000, 19, 299-309. [CrossRef]

9. Kotila-Row, A. Detection of Elephant Endotheliotropic Herpesvirus (EEHV) in Asian (Elephas maximus) and African Elephants (Loxodonta africana). Bachelor's Thesis, Swedish University of Agricultural Sciences, Uppsala, Sweden, 2015.

10. Wilkie, G.S.; Davison, A.J.; Watson, M.; Kerr, K.; Sanderson, S.; Bouts, T.; Steinbach, F.; Dastjerdi, A. Complete Genome Sequences of Elephant Endotheliotropic Herpesviruses 1A and 1B Determined Directly from Fatal Cases. J. Virol. 2013, 87, 6700-6712. [CrossRef]

11. Sripiboon, S.; Jackson, B.; Ditcham, W.; Holyoake, C.; Robertson, I.; Thitaram, C.; Tankaew, P.; Letwatcharasarakul, P.; Warren, K. Molecular Characterisation and Genetic Variation of Elephant Endotheliotropic Herpesvirus Infection in Captive Young Asian Elephants in Thailand. Infect. Genet. Evol. 2016, 44, 487-494. [CrossRef]

12. Zong, J.-C.; Latimer, E.; Heaggans, S.Y.; Richman, L.; Hayward, G.S. Viral Gene Subtyping of Eighteen North American Cases of EEHV Hemorrhagic Disease. In Proceedings of the International Elephant Conservation and Research Symposium, Bangkok, Thailand, 11-13 November 2009. 
13. Zong, J.-C.; Latimer, E.; Heaggans, S.Y.; Richman, L.; Hayward, G.S. Pathogenesis and Molecular Epidemiology of Fatal Elephant Endotheliotropic Disease Associated with the Expanding Proboscivirus Genus of the Betaherpesvirinae. In Proceedings of the International Elephant Conservation and Research Symposium, Orlando, FL, USA, 2-3 November 2007.

14. Richman, L.K.; Zong, J.-C.; Latimer, E.M.; Lock, J.; Fleischer, R.C.; Heaggans, S.Y.; Hayward, G.S. Elephant Endotheliotropic Herpesviruses EEHV1A, EEHV1B, and EEHV2 from Cases of Hemorrhagic Disease are Highly Diverged from Other Mammalian Herpesviruses and May Form a New Subfamily. J. Virol. 2014, 88, 13523-13546. [CrossRef]

15. Seilern-Moy, K.; Bertelsen, M.; Leifsson, P.; Perrin, K.; Haycock, J.; Dastjerdi, A. Fatal Elephant Endotheliotropic Herpesvirus-1 and 4 Co-Infection in a Juvenile Asian Elephant in Europe. JMM Case Rep. 2015, 3, e005005. [CrossRef]

16. Zong, J.-C.; Heaggans, S.Y.; Long, S.Y.; Latimer, E.M.; Nofs, S.A.; Bronson, E.; Casares, M.; Fouraker, M.D.; Pearson, V.R.; Richman, L.K.; et al. Detection of Quiescent Infections with Multiple Elephant Endotheliotropic Herpesviruses (EEHVs), Including EEHV2, EEHV3, EEHV6, and EEHV7, within Lymphoid Lung Nodules or Lung and Spleen Tissue Samples from Five Asymptomatic Adult African Elephants. J. Virol. 2016, 90, 3028-3043. [CrossRef]

17. Garner, M.; Helmick, K.; Ochsenreiter, J.; Richman, L.K.; Latimer, E.; Wise, A.; Maes, R.; Kiupel, M.; Nordhausen, R.; Zong, J. Clinico-Pathologic Features of Fatal Disease Attributed to New Variants of Endotheliotropic Herpesviruses in Two Asian Elephants (Elephas maximus). Vet. Pathol. 2009, 46, 97-104. [CrossRef] [PubMed]

18. Kochagul, V.; Srivorakul, S.; Boonsri, K.; Somgird, C.; Sthitmatee, N.; Thitaram, C.; Pringproa, K. Production of Antibody against Elephant Endotheliotropic Herpesvirus (EEHV) Unveils Tissue Tropisms and Routes of Viral Transmission in EEHV-Infected Asian Elephants. Sci. Rep. 2018, 8, 4675. [CrossRef] [PubMed]

19. Latimer, E.; Zong, J.-C.; Heaggans, S.Y.; Richman, L.K.; Hayward, G.S. Detection and Evaluation of Novel Herpesviruses in Routine and Pathological Samples from Asian and African Elephants: Identification of Two New Probosciviruses (EEHV5 and EEHV6) and Two New Gammaherpesviruses (EGHV3B and EGHV5). Vet. Microbiol. 2011, 147, 28-41. [CrossRef] [PubMed]

20. Perrin, K.L.; Kristensen, A.T.; Bertelsen, M.F.; Denk, D. Retrospective Review of 27 European Cases of Fatal Elephant Endotheliotropic Herpesvirus-Haemorrhagic Disease Reveals Evidence of Disseminated Intravascular Coagulation. Sci. Rep. 2021, 11, 14173. [CrossRef]

21. Denk, D.; Stidworthy, M.; Redrobe, S.; Latimer, E.; Hayward, G.; Cracknell, J.; Dastjerdi, A. Fatal Elephant Endotheliotropic Herpesvirus Type 5 Infection in a Captive Asian Elephant. Vet. Rec. 2012, 171, 380-381. [CrossRef]

22. Wilkie, G.S.; Davison, A.J.; Kerr, K.; Stidworthy, M.F.; Redrobe, S.; Steinbach, F.; Dastjerdi, A.; Denk, D. First Fatality Associated with Elephant Endotheliotropic Herpesvirus 5 in an Asian Elephant: Pathological Findings and Complete Viral Genome Sequence. Sci. Rep. 2014, 4, 6299. [CrossRef]

23. Srivorakul, S.S.; Guntawang, T.; Kochagul, V.; Photichai, K.; Sittisak, T.; Janyamethakul, T.; Boonprasert, K.; Khammesri, S.; Langkaphin, W.; Punyapornwithaya, V.; et al. Possible roles of monocytes/macrophages in response to elephant endotheliotropic herpesvirus (EEHV) infections in Asian elephants (Elephas maximus). PLoS ONE 2019, 14, e0222158. [CrossRef]

24. Fuery, A.; Pursell, T.; Tan, J.; Peng, R.; Burbelo, P.D.; Hayward, G.S.; Ling, P.D. Lethal Hemorrhagic Disease and Clinical Illness Associated with Elephant Endotheliotropic Herpesvirus 1 Are Caused by Primary Infection: Implications for the Detection of Diagnostic Proteins. J. Virol. 2020, 94, e01528-19. [CrossRef]

25. Long, S.Y. Novel Molecular and Genomic Aspects of Elephant Endotheliotropic Herpesvirus (EEHV). Ph.D. Thesis, Johns Hopkins University, Baltimore, MD, USA, 2017. Available online: http://jhir.library.jhu.edu/handle/1774.2/59324 (accessed on 15 December 2021).

26. Haycock, J. Exploring the Innate Immune System of the Asian Elephant (Elephas maximus) to Control Elephant Endotheliotropic Herpesvirus Infection. Ph.D. Thesis, University of Surrey, Surrey, UK, 2020.

27. Richman, L.K.; Montali, R.J.; Cambre, R.C.; Schmitt, D.; Hardy, D.; Hildbrandt, T.; Bengis, R.G.; Hamzeh, F.M.; Shahkolahi, A.; Hayward, G.S. Clinical and Pathological Findings of a Newly Recognized Disease of Elephants Caused by Endotheliotropic Herpesviruses. J. Wildl. Dis. 2000, 36, 1-12. [CrossRef]

28. Boonprasert, K.; Punyapornwithaya, V.; Tankaew, P.; Angkawanish, T.; Sripiboon, S.; Titharam, C.; Brown, J.; Somgird, C. Survival Analysis of Confirmed Elephant Endotheliotropic Herpes Virus Cases in Thailand from 2006-2018. PLoS ONE 2019, 14, e0219288. [CrossRef] [PubMed]

29. Kendall, R.; Howard, L.; Masters, N.; Grant, R. The Impact of Elephant Endotheliotropic Herpesvirus on the Captive Asian Elephant (Elephas maximus) Population of the United Kingdom and Ireland (1995-2013). J. Zoo Wildl. Med. 2016, 47, 405-418. [CrossRef] [PubMed]

30. Stanton, J.J.; Zong, J.-C.; Latimer, E.; Tan, J.; Herron, A.; Hayward, G.S.; Ling, P.D. Detection of Pathogenic Elephant Endotheliotropic Herpesvirus in Routine Trunk Washes from Healthy Adult Asian Elephants (Elephas maximus) by Use of a Real-Time Quantitative Polymerase Chain Reaction Assay. Am. J. Vet. Res. 2010, 71, 925-933. [CrossRef] [PubMed]

31. Dastjerdi, A.; Seilern-Moy, K.; Darpel, K.; Steinbach, F.; Molenaar, F. Surviving and Fatal Elephant Endotheliotropic Herpesvirus1A Infections in Juvenile Asian Elephants-Lessons Learned and Recommendations on Anti-Herpesviral Therapy. BMC Vet. Res. 2016, 12, 1-11. [CrossRef]

32. Wissink-Argilaga, N.; Dastjerdi, A.; Molenaar, F.M. Using In-House Hematology to Direct Decision-Making in the Successful Treatment and Monitoring of a Clinical and Subsequently Subclinical Case of Elephant Endotheliotropic Herpesvirus 1B. J. Zoo Wildl. Med. 2019, 50, 498-502. [CrossRef] 
33. Mahato, G.; Sarma, K.K.; Pathak, D.C.; Barman, N.N.; Gogoi, P.; Dutta, M.; Basumatary, P. Endotheliotropic Herpesvirus Infection in Asian Elephants (Elephas maximus) of Assam, India. Vet. World 2019, 12, 1790-1796. [CrossRef]

34. Edwards, K.L.; Miller, M.A.; Carlstead, K.; Brown, J.L. Relationships between Housing and Management Factors and Clinical Health Events in Elephants in North American Zoos. PLoS ONE 2019, 14, e0217774. [CrossRef]

35. Schaftenaar, W.; Reid, C.; Martina, B.; Fickel, J.; Osterhaus, A. Nonfatal Clinical Presentation of Elephant Endotheliotropic Herpes Virus Discovered in a Group of Captive Asian Elephants (Elephas maximus). J. Zoo Wildl. Med. 2010, 41, 626-632. [CrossRef]

36. Molenaar, F.; Schaftenaar, W. Letter: Should We Treat Elephants with EEHV? Vet. Rec. 2020, 186, 222. [CrossRef]

37. Angkawanish, T.; Nielen, M.; Vernooij, H.; Brown, J.L.; van Kooten, P.J.S.; van den Doel, P.B.; Schaftenaar, W.; Na Lampang, K.; Rutten, V.P.M.G. Evidence of High EEHV Antibody Seroprevalence and Spatial Variation among Captive Asian Elephants (Elephas maximus) in Thailand. Virol. J. 2019, 16, 33. [CrossRef]

38. Perrin, K.; (University of Copenhagen, Copenhagen, Denmark). Personal Communication: Facilities without a History of EEHV Fatality, 2021.

39. Hengtrakul, P.; Sudlapa, P.; Chaisurat, N.; Sodsaengthien, S.; Chamnankij, C.; Noimoon, S.; Punkong, C.; Phatthanakunanan, S.; Lertwatcharasarakul, P.; Sripiboon, S. Biological and Environmental Factors Associated with the Detection of Elephant Endotheliotropic Herpesvirus in Asian Elephants (Elephas maximus) in Thailand. J. Vet. Med. Sci. 2020, 82, 1808-1815. [CrossRef] [PubMed]

40. Ackermann, M.; Hatt, J.-M.; Schetle, N.; Steinmetz, H. Identification of Shedders of Elephant Endotheliotropic Herpesviruses among Asian Elephants (Elephas maximus) in Switzerland. PLoS ONE 2017, 12, e0176891. [CrossRef] [PubMed]

41. Atkins, L.; Zong, J.; Tan, J.; Mejia, A.; Heaggans, S.; Nofs, S.; Stanton, J.; Flanagan, J.; Howard, L.; Latimer, E. EEHV-5, a Newly Recognized Elephant Herpesvirus Associated with Clinical and Subclinical Infections in Captive Asian Elephants (Elephas maximus). J. Zoo Wildl. Med. 2013, 44, 136-143. [CrossRef] [PubMed]

42. Sanchez, C.R.; Wagener, T.; Nevitt, D.; Latimer, E.; Brown, J. Correlation between Serum and Urinary Cortisol Levels and Shedding of Elephant Endotheliotropic Herpesvirus (EEHV) 1, 3, 4 and 5 in Calves and Adult Asian Elephants (Elephas maximus) Pre-and Post-arrival of a New Bull Elephant; American Association of Zoo Veterinarians Yulee, FL: Atlanta, GA, USA, 2016; pp. 43-44.

43. Bennett, L.; Dunham, S.; Yon, L.; Chapman, S.; Kenaghan, M.; Purdie, L.; Tarlinton, R. Longitudinal Study of Asian Elephants, Elephas maximus, Indicates Intermittent Shedding of Elephant Endotheliotropic Herpesvirus 1 during Pregnancy. Vet. Rec. Open 2015, 2, e000088. [CrossRef]

44. Jeffrey, A.; Evans, T.S.; Molter, C.; Howard, L.L.; Ling, P.; Goldstein, T.; Gilardi, K. Noninvasive Sampling for Detection of Elephant Endotheliotropic Herpesvirus and Genomic DNA in Asian (Elephas maximus) and African (Loxodonta africana) Elephants. J. Zoo Wildl. Med. 2020, 51, 433-437. [CrossRef]

45. Kölpin, T.; Pluhackova, J. EAZA Best Practice Guidelines for Elephants; Elephant Taxon Advisory Group Second Edition; EAZA: Leipzig, Germany, 2020; p. 214.

46. Haycock, J.; Seilern-Moy, K.; Molenaar, F.; Dastjerdi, A. Refining a Multiplex QPCR Assay to Simultaneously Detect Elephant Endotheliotropic Herpesvirus Infections in Asian Elephants (Elephas maximus). In Proceedings of the 10th International Elephant Endotheliotropic Herpesvirus (EEHV) Workshop, Houston, TX, USA, 17-18 February 2015; Available online: https:/ / eehvinfo. org/wp-content/uploads/2016/07/10th-EEHV-workshop-Proceedings-2015-FINAL.pdf (accessed on 15 December 2021).

47. Dheda, K.; Huggett, J.; Bustin, S.; Johnson, M.; Rook, G.; Zumla, A. Validation of Housekeeping Genes for Normalizing RNA Expression in Real-Time PCR. BioTechniques 2004, 37, 112-119. [CrossRef]

48. Pfaffl, M.W. A New Mathematical Model for Relative Quantification in Real-Time RT-PCR. Nucleic Acids Res. 2001, 29 , e45. [CrossRef]

49. Antonov, J.; Goldstein, D.R.; Oberli, A.; Baltzer, A.; Pirotta, M.; Fleischmann, A.; Altermatt, H.J.; Jaggi, R. Reliable Gene Expression Measurements from Degraded RNA by Quantitative Real-Time PCR Depend on Short Amplicons and a Proper Normalization. Lab. Investig. 2005, 85, 1040-1050. [CrossRef]

50. Hardin, J.W. Generalized Estimating Equations (GEE). In Encyclopedia of Statistics in Behavioral Science; American Cancer Society: Atlanta, GA, USA, 2005. [CrossRef]

51. Seilern-Moy, K.; Darpel, K.; Steinbach, F.; Dastjerdi, A. Distribution and Load of Elephant Endotheliotropic Herpesviruses in Tissues from Associated Fatalities of Asian Elephants. Virus Res. 2016, 220, 91-96. [CrossRef]

52. Stanton, J.J.; Zong, J.-C.; Eng, C.; Howard, L.; Flanagan, J.; Stevens, M.; Schmitt, D.; Wiedner, E.; Graham, D.; Junge, R.E. Kinetics of Viral Loads and Genotypic Analysis of Elephant Endotheliotropic Herpesvirus-1 Infection in Captive Asian Elephants (Elephas maximus). J. Zoo Wildl. Med. 2013, 44, 42. [CrossRef]

53. Molenaar, F.M.; Sylvestre, P. Clinical approach to colic and collapse in an Asian elephant (Elephas maximus) with Salmonella saintpaul septicaemia and subsequent ileus. Vet. Rec. Case Rep. 2021, e214. [CrossRef]

54. Phillips, T.R.; Jensen, J.L.; Rubino, M.J.; Yang, W.C.; Schultz, R.D. Effects of Vaccines on the Canine Immune System. Can. J. Vet. Res. 1989, 53, 154-160. [PubMed]

55. Rasmussen, L.E.L. Chemical Communication: An Integral Part of Functional Asian Elephant (Elephas maximus) Society. Écoscience 1998, 5, 410-426. [CrossRef]

56. Hildebrandt, T.B.; Göritz, F.; Hermes, R.; Reid, C.; Dehnhard, M.; Brown, J.L. Aspects of the Reproductive Biology and Breeding Management of Asian and African Elephants Elephas maximus and Loxodonta africana. Int. Zoo Yearb. 2006, 40, 20-40. [CrossRef] 
57. Thitaram, C.; Chansitthiwet, S.; Pongsopawijit, P.; Brown, J.L.; Wongkalasin, W.; Daram, P.; Roongsri, R.; Kalmapijit, A.; Mahasawangkul, S.; Rojanasthien, S.; et al. Use of Genital Inspection and Female Urine Tests to Detect Oestrus in Captive Asian Elephants. Anim. Reprod. Sci. 2009, 115, 267-278. [CrossRef]

58. Koirala, R.K.; Ji, W.; Aryal, A.; Rothman, J.; Raubenheimer, D. Dispersal and Ranging Patterns of the Asian Elephant (Elephas maximus) in Relation to Their Interactions with Humans in Nepal. Ethol. Ecol. Evol. 2016, 28, 221-231. [CrossRef]

59. Coleman, M.; Martinez, R.; Trujillo, R.; Nazari-Shafti, T. Stem Cell Technology and Its Application to EEHV. In Proceedings of the 10th International Elephant Endotheliotropic Herpesvirus (EEHV) Workshop, Houston, TX, USA, 17-18 February 2015 ; p. 30.

60. D'Agostino, J. The Use of Mesenchymal Stem Cells as Part of a Therapeutic Plan for Elephant Endotheliotropic Herpesvirus (EEHV). In Proceedings of the North American EEHV Workshop, Houston, TX, USA, 26-28 March 2019; p. 43.

61. Fuery, A.; Leen, A.; Peng, R.; Wong, M.; Liu, H.; Ling, P. Asian Elephant T Cell Responses to Elephant Endotheliotropic Herpesvirus. J. Virol. 2018, 92, 6. [CrossRef]

62. Fuery, A.; Peng, R.; Tan, J.; Howard, L.; Ling, P. Establishing assays to evaluate T cell responses to Elephant Endotheliotropic Herpesvirus (EEHV). In Proceedings of the First European EEHV Research Workshop, Rotterdam, The Netherlands, 19-20 May 2016; p. 18. 